\title{
DOUBLE ENTRY JOURNAL TECHNIQUE FOR THE STUDENTS' READING COMPREHENSION
}

(A Classroom Action Research at the Second Grade Students of SMA Neg. 1 Pasui)

Teknik Jurnal Double Entry Untuk Pemahaman Membaca Siswa

(Sebuah Penelitian Tindakan Kelas Pada Siswa Semester Kedua di SMA Neg. 1 Pasui)

\section{Bahrun Amin}

English Education Department, Faculty of Teacher Training and Education Muhammadiyah University of Makassar aminbahrun@gmail.com

\begin{abstract}
The objective of the research is to know the improvement of the students' reading comprehension using double entry journal technique at the second year students' of SMA Neg. 1 Pasui. This research is a classroom action research consist of two cycles, the mean score of the students' reading comprehension for diagnostic-Test is 5.95 which is categorized as poor classification. While the mean score of the students' reading comprehension in cycle I was 6.39. It is higher than the students" D-Test. But the result was still not significant, because it is still categorized as fair and under the KKM 60. So the research is continued to the cycle II and the mean score of the students' reading comprehension of cycle II was 6.82. Having analyzed the data, it can be stated that the students' reading comprehension at the second year in class XI of SMA Neg.I Pasui is poor level before applying the double entry journal technique, but after applying the technique in the second cycle, the students' reading comprehension is classified as good categories.
\end{abstract}

Key words: Reading Comprehension, Double Entry Journal Technique.

Tujuan dari penelitian ini adalah untuk mengetahui peningkatan pemahaman membaca siswa menggunakan teknik jurnal double entry pada siswa tahun kedua di SMA Neg. 1 Pasui. Penelitian ini merupakan penelitian tindakan kelas terdiri dari dua siklus, nilai rata-rata dari pemahaman membaca siswa untuk diagnostik-Test adalah 5.95 yang dikategorikan sebagai klasifikasi kurang. Sementara nilai rata-rata dari membaca pemahaman siswa pada siklus I adalah 6, 39. Ini lebih tinggi dari D-Test siswa. Tapi hasilnya masih belum signifikan, karena masih dikategorikan sebagai cukup dan di bawah KKM 60. Jadi penelitian dilanjutkan ke siklus II dan nilai rata-rata dari pemahaman membaca siswa dari siklus II adalah 6.82. Setelah menganalisis data, dapat dinyatakan bahwa pemahaman membaca siswa di tahun kedua pada kelas XI SMA Neg.1 Pasui adalah tingkatan kurang sebelum menerapkan teknik jurnal double entry, tapi setelah menerapkan teknik dalam siklus kedua, pemahaman membaca siswa diklasifikasikan sebagai kategori baik.

Kata Kunci: Membaca Pemahaman, Double Masuk Journal Teknik.

Reading is one of the four language skills that should be mastered in language learning. It is usually taught and integrated with the other language skills (listening, speaking, and writing) Generally, the teaching of reading as a foreign language (EFL reading) in Indonesia aims at enabling students to read and comprehend the texts and other materials written in English. Students are expected to master skills in the level of literal, interpretative, and creative 
comprehension. It is shown in the most of students' handbook content that is dominated in text. Unfortunately, Indonesian students are still lack of skills in reading comprehension. Especially, the results of the preliminary study conducted at SMA Negeri 1 Pasui. It shows that students in this school get difficulties in answering questions related to English texts given to them. Besides that, the students' average score of reading achievements conducted in the preliminary study is quite poor.

Journal entry technique let the students to read the text and also give them opportunities to discuss or share their problems with their friends. Moreover, this technique is very useful because it can be used as a tool to increase the students' speaking ability in the form of class discussion.

Using this technique, teacher asks the students to write down what they think interesting in the reading text. Besides, the students are also encouraged to write any questions, confusion related to a text. The students may also write some responses to the text. That why this is called as a journal entry technique. By reading this journal, the teacher can make a judgment about the students understanding.

\section{CONCEPTS OF JOURNAL-ENTRY TECHNIQUE}

According to Bromley, 1993" an effective technique to foster the students' active connection with the literary texts is the reader response activity of entryjournaling. Journal entry technique is a strategy which enables the students to record their responses to text in preparation for class discussion. The students have the opportunity to express their thoughts and become actively involved with the material they read. As the corner stone of such a communications method, student journals have proven simple, yet effective". In this technique, teacher introduces a passage of text to the students, then the students write a response to a particular quotation from the reading text, which they think the most interesting or the most difficult part. After that, they bring their journal into the class to do a discussion, to do a paired annotation, or for group activity.

Gay (1981) said that, before the students select what they are going to read, they are asked to write down what they know of the topic so as to activate 
their real world knowledge. While reading, the students are asked to focus on the main ideas by reading the first sentence only of each paragraph on their initial reading and keep notes in their reading journal, then through subsequent readings and underlining of two to three phrases in each paragraph, they are required to create a mind map of the key points. In class, they then use their notes and mind maps as a basis for pair discussions, and write a summary of their discussion.

According to Hammer (1981) the next phase, students are asked each week to find an English newspaper article of personal interest to them (between 300 and 500 words long) to prepare it in the following way before class. First, they cut it out and stick in their reading journal. Next, they read through the article to find answers to these cues: Who? What? When? Where? How? Third, they are to choose no more than six key phrases from the text, to copy these into their journals, to use their dictionaries to write paraphrases in English. Then, they are required to write a summary of the main points, and to finish this with their personal comments about the topic. Again, in class, they use their notes and summaries to give mini presentations in pairs as a basis for discussion and for explaining key vocabulary to each other. In the final phase, students then apply everything that has gone before they are asked to choose books from their own major; to read twenty non-consecutive pages; to prepare mind maps; to perform lexical analysis; to write a response summary; to present and discuss the contents of the book in pairs; to write a final self-assessment.

The double-entry journal is a two-column journal. In the left column, students write a piece of information from the text, such as a quotation or a concept, which students want to expand upon, understand better, or question. In the right column, students relate to or analyze the information that is written in the left column. For example, the student could title the left column "Critical Points" and the right column "Response."

\begin{tabular}{|c|c|}
\hline Critical Points & Response \\
\hline $\begin{array}{l}\text { "Learning Styles" have been } \\
\text { over-emphasized in the research } \\
\text { literature. }\end{array}$ & $\begin{array}{l}\text { I would agree! I have never been comfortable with so many } \\
\text { different typologies. I have taken courses in the Myers-Briggs } \\
\text { instrument, 4-MAT, etc., and I have never understood the } \\
\text { distinctions and values. Other than the truism that we should } \\
\text { vary our teaching methods, the learning styles information has } \\
\text { been of little practical value for me as a faculty developer and } \\
\text { as a teacher. }\end{array}$ \\
\hline Many students don't get the point & As a composition/literature teacher, this fact is no Revelation \\
\hline
\end{tabular}




\begin{tabular}{|l|l|}
\hline $\begin{array}{l}\text { of what they are reading because } \\
\text { they aren't looking for it. }\end{array}$ & $\begin{array}{l}\text { to me. I am concerned now in my Eng. 211 class that students } \\
\text { truly learn to apply literary concepts and that they learn to } \\
\text { explicate a piece of literature. }\end{array}$ \\
\hline $\begin{array}{l}\text { Students often adopt a surface } \\
\text { approach to reading by seeking } \\
\text { facts they will be tested on, not } \\
\text { the underlying meaning. }\end{array}$ & $\begin{array}{l}\text { Issues of intrinsic versus extrinsic motivation have always } \\
\text { concerned me. I found the adult military students I taught } \\
\text { overseas to be far more motivated -on the whole--than the } \\
\text { cadets I have observed or taught so far. I can understand why } \\
\text { this is the case, but it is always troubling to a teacher when } \\
\text { students do not share her passion for the subject matter. I use } \\
\text { IP points to motivate cadets to prepare for my classes, tying } \\
\text { them in with structured pre assignments. }\end{array}$ \\
\hline \multicolumn{2}{|c|}{ Joyce (2008) mentions some benefits of this entry as follows: }
\end{tabular}

1. Students make their own meaning of information in the non-threatening conditions. They can reflect their own ideas while interacting with the information. As a result, they feel free to use any words or phrases that best reflect their ideas.

2. Teacher becomes partner with the students in the learning process. In traditional classrooms, students frequently look at the teacher as the threatening individual who assigns the grade. Their success or failure depends on teacher's evaluation. Through the use of Journal Entry technique, teacher becomes partner with the students. They work as a team as they develop their ideas.

3. Journal Entry Technique is concrete evidence of students learning. Teacher keeps students' journal on file. When parents ask about their children' progress, teacher can show them students' journal with teacher's comments. With Journal Entry Technique, the students and teacher are held accountable for their share of the learning process.

\section{CONCEPTS OF MAIN IDEA AND FACT}

\section{Main Idea}

The author's message, idea, point, concept, or meaning he or she wants to portray to the reader is what is known as the main idea of the passage. It may also be referred to as the controlling idea, central idea, or gist. We, as the reader, must understand the importance in grasping the main idea the author portrays. The main idea is commonly found in the beginning and is followed by supporting sentences. Very often the writer begins with supporting evidence and places the main idea in the last sentence. Sometimes the writer uses a few sentences to introduce the 
topic, places the main idea in the middle and follows it with supporting sentences. So, the main idea may be stated at the beginning, middle, or end. The main idea of a passage falls into two types. The two types of main idea are stated main idea and implied main idea. A stated main idea is openly expressed in a sentence or two. It is either in the passage or individual paragraphs. They are usually, but not necessarily, located in the first or last sentence. Implied main idea cannot be immediately pointed out by skimming the passage. It is derived from various places in the text.

\section{Fact}

The word fact can refer to verified information about past or present circumstances or events which are presented as objective reality. In science, it means a provable concept. A fact is something that is empirically true and can be supported by evidence. A statement of fact expresses only what actually happened, or what could be proven by objective data. Questions of objectivity and $\underline{\text { truth }}$ are closely associated with questions of fact.

\section{METHODOLOGY}

This research uses classroom action research (CAR). The research will be conducted in SMA Negeri 1 Pasui in August-September 2011-2012 academic year

The research subject is the eleventh year students of SMA in 2011-2012 academic years. The class consists of 30 students with 18 women and 12 men.

The Independent variable of this research is the Journal-Entry Technique; the important process to increasing the student's reading comprehension. While Dependent variable of the research is the students' literal and interpretative comprehension. There are three instruments used namely observation sheet aims at finding out the students' data about their presence and activeness in teaching learning process, questionnaire aims at finding out the students' responses toward teaching learning process by using Journal-Entry Techniques, and Facts test whish was to get information about students' reading improvement after teaching learning process end. 
Scoring the students' correct answer in reading comprehension:

\begin{tabular}{|l|l|l|}
\hline No & Criteria & Score \\
\hline 1 & The answer, grammar, and vocabulary used is correct & 4 \\
\hline 2 & The answer and grammar are correct, vocabulary used is incorrect & 3 \\
\hline 3 & The answer and vocabulary are correct, garmmar incorrect & 2 \\
\hline 4 & The answer grammar, and vocabulary are wrong & 1 \\
\hline 5 & 0 answer & 0 \\
\hline
\end{tabular}

\section{FINDINGS}

After applying the Double Entry Journal technique in teaching of reading comprehension, it shows that the use of Double Entry Journal technique is effective to improve the students' achievement of SMA Negeri I Pasui in Enrekang regency. The students' improved significantly; the result of the mean score in cycle I and cycle II can be seen in the table below:

\section{The Students' Mean Score}

Table 1: The Students' Mean Score

\begin{tabular}{|l|l|l|l|}
\hline Mean score & D-Test & Cycle I & Cycle II \\
\hline \multirow{2}{*}{ Classification } & 5.95 & 6.39 & 6.82 \\
\cline { 2 - 4 } & Poor & fair & $\begin{array}{l}\text { Fairly } \\
\text { good }\end{array}$ \\
\hline
\end{tabular}

Table I shows that there is improvement of the students' mean score between D-Test (before given Double Entry Journal) and cycle I and cycle II.

\section{The Students' Reading Improvement in Literal Comprehension}

Table 2: Reading Improvement in Literal Comprehension

\begin{tabular}{|l|l|l|l|l|}
\hline \multicolumn{2}{|l|}{ The Students' Reading Comprehension } \\
\cline { 1 - 4 } Cycles & Main Idea & Fact & Mean Score & $\begin{array}{l}\text { Improvement } \\
\text { ( C I to C II) }\end{array}$ \\
\hline Cycle I & 6.62 & 6.54 & 6.38 & \multirow{2}{*}{5.95} \\
\hline Cycle II & 6.61 & 6.92 & 6.76 & \\
\hline
\end{tabular}

The table of above shows that mean score and it proves that the use Double Entry Journal technique could improve the students' achievement in reading comprehension. In analyzing the data statistically of this treatment result, the researcher applied the mean score to measure the students' achievement in reading comprehension after applying Double Entry Journal technique in teaching reading comprehension could improve the students' achievement more significantly the achievement of the students' the pre-test. 


\section{The Students' Reading Improvement in Interpretative Comprehension}

Table 3: Reading Improvement in Interpretative Comprehension

\begin{tabular}{|l|l|l|l|l|}
\hline \multicolumn{5}{|l|}{ The Students' Reading Comprehension } \\
\cline { 1 - 5 } Cycle & $\begin{array}{l}\text { Cause Effect } \\
\text { Relation }\end{array}$ & Making Prediction & Mean score & $\begin{array}{l}\text { Improvement } \\
\text { (C I to C II) }\end{array}$ \\
\hline Cycle I & 6.18 & 6.75 & 6.46 & 5.57 \\
\hline Cycle II & 6.63 & 7.02 & 6.82 & 5.5 \\
\hline
\end{tabular}

The table above shows that there is a significant improvement of the students' achievement in second test. And it can be concluded that the students' achievement in second test is the highest.

\section{The Rate Percentage of Students' Score in The Cycle I}

Table 4: The Rate Percentage of Students' Score in the Cycle I

\begin{tabular}{|c|c|c|c|c|c|c|}
\hline \multirow{2}{*}{ No. } & \multirow{2}{*}{$\begin{array}{l}\text { Achievement } \\
\text { Categories }\end{array}$} & \multirow{2}{*}{ Score } & \multicolumn{2}{|l|}{ D-Test } & \multicolumn{2}{|l|}{ Cycle I } \\
\hline & & & Frequently & $\%$ & Frequently & $\%$ \\
\hline 1 & Excellent & $9.6-10$ & 0 & $0 \%$ & 0 & $0 \%$ \\
\hline 2 & Very Good & $8.6-9.5$ & 1 & $3.3 \%$ & 2 & $6.6 \%$ \\
\hline 3 & Good & $7.6-8.5$ & 1 & $3.3 \%$ & 4 & $13.2 \%$ \\
\hline 4 & Fairly Good & $6.6-7.5$ & 2 & $6.6 \%$ & 3 & $10 \%$ \\
\hline 5 & Fair & $5.6-6.5$ & 7 & $23.3 \%$ & 4 & $13.2 \%$ \\
\hline 6 & Poor & $3.6-5.5$ & 16 & $53.3 \%$ & 17 & $56.6 \%$ \\
\hline 7 & Very Poor & $0-3.5$ & 3 & $10 \%$ & 0 & $0 \%$ \\
\hline & Total & & 30 & $100 \%$ & 30 & $100 \%$ \\
\hline
\end{tabular}

The data of the students' achievement in the rate percentage of score shows that none of students' could the excellent classification in pre-test. There is only one student get very good classification (3.3\%) and also one for good classification (3.3\%). There are two students' score classified as fairly good $(6.6 \%)$ seven students' score $(23.3 \%)$ classified as fair, and more than a half number of students' classified as poor $(53.3 \%$. there are three score of the students' classified as very poor (10\%). The achievement of the students' in the first cycle reading comprehension through Double Entry Journal technique shows that there is no more students' score classified as very poor, most their score still classified as poor (56.6\%). There are four students' classified as good (13.2\%) and two classified as very good (6.6\%). The table describes the improvement of the students' score in reading comprehension taught by using Double Entry Journal technique. It means the teaching of reading comprehension through Double Entry Journal technique gets success quite significant and it is effective to improve the students' achievement because the result of post-test of cycle I higher than pre- 
test. For the clear scores of whole pre and post-test of cycle I could be seen in appendix.

\section{The Rate Percentage of Students' Score in the Cycle I and Cycle II}

Table 5: The Rate Percentage of Students' Score in the Cycle I and Cycle II

\begin{tabular}{|l|l|l|l|l|l|l|}
\hline \multirow{2}{*}{ No. } & Achievement & \multirow{2}{*}{ Score } & \multicolumn{2}{|c|}{ Cycle I } & \multicolumn{2}{c|}{ Cycle II } \\
\cline { 4 - 7 } & Categories & & Frequently & \% & Frequently & \% \\
\hline 1 & Excellent & $9.6-10$ & 0 & $0 \%$ & 0 & $0 \%$ \\
\hline 2 & Very Good & $8.6-9.5$ & 2 & $6.6 \%$ & 3 & $10 \%$ \\
\hline 3 & Good & $7.6-8.5$ & 4 & $13.2 \%$ & 3 & $10 \%$ \\
\hline 4 & Fairly Good & $6.6-7.5$ & 3 & $10 \%$ & 6 & $20 \%$ \\
\hline 5 & Fairly & $5.6-6.5$ & 4 & $13.2 \%$ & 12 & $40 \%$ \\
\hline 6 & Poor & $3.6-5.5$ & 17 & $56.6 \%$ & 6 & $20 \%$ \\
\hline 7 & Very Poor & $0-3.5$ & 0 & $0 \%$ & 0 & $0 \%$ \\
\hline & Total & & 30 & $100 \%$ & 30 & $100 \%$ \\
\hline
\end{tabular}

\section{DISCUSSION}

The result of the finding shows that the strategy of double entry journal technique can improve the student achievement in reading comprehension. They are able to understand the material given well. It can be seen by their mean score of the cycle I (6.48) and cycle II (6.86). They second cycle higher than cycle I and D-Test. After seeing the result of all research findings, there are still many students' get low and it is still far from perfect. In first post-test, more than a half number of students seventeen get poor (56.6\%), four students classified as fair $(13.2 \%)$, there are classified as fairly good (10\%), four classified as good (13.2\%) and there are two students classified as very good (6.6\%).

The rate percentage of the student achievement in second test shows significant improvement of student achievement in reading comprehension. The number of students' who get poor in cycle II is lower (20\%) than cycle I (56.6\%). The highest improvement of the students' achievement in cycle II is in fair classification, from fur students' (13.2\%), to 12 students' (40\%). Six students' classified as fairly good (20\%), there are students' classified as good (10\%) and also three as very good (10\%). It sign that giving second cycle is very important because it can help to overcome the students' weakness in cycle I. At the end of the cycle I, the research made a reflection to see the weakness and then made a correction. The result of the reflection showed the positive impact in the second 
cycle. The students' more active than before because the changing of the way in learning.

\section{CONCLUSION}

The use of double entry journal technique in presenting the reading comprehension material at students of class XII of SMA Neg. I Pasui in Enrekang improved the students' achievement significantly. It can be concluded that the application of double entry journal technique in teaching reading comprehension is effective to improve the students' reading achievement of SMA Neg. I Pasui in Enrekang regency.

\section{REFERENCES}

Bruchac, Joseph and Francisco Jimenez. 2008. Double-Entry Journal. Annenberg Media. $\quad$ Retrieved from http://www.learner.org/channel/workshops/tml/workshop8/teaching.html $\underline{12: 48}$, on 26 May 2000.

Cobine, Gary. 1995. Effective Use of Student Journal Writing. Eric Digest.

Depdikbud, 1985. Garis-garis Besar Program Pelajaran Mata Pelajaran Bahasa Inggris Kurikulum Sekolah Menengah Umum. Dirjen Dikdasman

Gay, LR, 1981. Educational Research Competencies for Analysis \& Application. Second Edition, London: Longman.

Grellet, Francoise. 1981. Developing Reading Skills. Cambridge: Cambridge University Press.

Hafidz, F.Mand Tudor. 1989. Extensive Reading and the Development of Language Skills. England: Oxford University Press.

Harmer, Jeremy. 1991. The Practice of English Language Teaching. London, Longman Group. .2008.WETA Washington, D.C. Double-Entry Journals. Retrieved from http://www.adlit.org/strategies/22091. 1:05, on 10 September 2009.

Hornby A.S, 1986. Oxford Advanced Dictionary of Current English. Great Britain: Oxford University Press.

Irawati, 1990, Developing Reading Comprehension. Kencana Prenada: Jakarta Layman. 1972. Teaching in testing. New York: Oxford University Press. 
Lutfiah, 2007. The Achievement students reading comprehension through Cooperative Learning

Magarita Calderon, Gary Ivory, Robert E, Slavin. 1997. Effects of bilingual Cooperative integrated reading and composition On students transitioning From Spanish to English reading. (Online) Retrieved from http://www.csos.jhu.edu/crespar/techReports/Report10.pdf, $\quad$ on 20 September 2011.

McCarty. 1999. Efficient reading a particle quite. Sidney: Mc. Graw Book Company

Sheldon, Leslie E. 1988. Evaluating ELT Textbooks and Materials. ELT Journal Volume 42/4 October 1988. Oxford University Press.

Simanjuntak, 1998. Developing Reading Skill for EFL Students. Jakarta: Depdikbud.

Sudjana. 1999. Metode statistika. Bandung: PT. Gramedia. 